\author{
\begin{tabular}{r|r} 
GARAI-FODOR Mónika Đ & \\
\hline $\begin{array}{r}\text { Óbudai Egyetem, } \\
\text { Keleti Károly Gazdasági Kar } \\
\text { Obuda University }\end{array}$ & \\
$\begin{array}{r}\text { Faculty of Business and Management } \\
\text { fodor.monika@kgk.uni-obuda.hu }\end{array}$ &
\end{tabular}
}

\section{ÉRTÉKRENDALAPÚ ÉLELMISZER-FOGYASZTÓI MAGATARTÁSRA VONATKOZÓ MINTÁK A Z GENERÁCIÓ KÖRÉBEN}

\author{
VALUE-BASED FOOD CONSUMER BEHAVIOUR \\ PATTERNS FOR THE Z GENERATION
}

This study is based on the value-based theories among the various behavioural sciences as the focus, which have the common characteristics of suggesting a connection between the reasons why consumers choose various products or services and the consumers' value systems. The primary research activities have been inspired by this base concept to find connections between value systems and consumer behaviour on my own. The main aim of this study is to analyse the foodstuff consumption habits of the $\mathrm{Z}$ Generation, or to be more precise, healthy eating habits. The other pillar of the topic is generation marketing, which also states that value systems are the differentiators among the different generations. Considering the $\mathrm{Z}$ generation as the potential customer base creating a demand, who are willing and capable of paying, it is fruitful and vital to know the specific foodstuff consumption preferences and decisions of this generation. During the primary research the study focuses on on the Z Generation's members, collecting qualitative and quantitative data, and conducting analyses on this generation's value system, foodstuff consumption behaviour, and their ideas about healthy eating habits. Based on the results, we can see the value orientation of the future generation, and understand how important they consider their own health, and what they do to preserve it. Beyond this, research results also help outline the relevant foodstuff consumption habits of the generation, which may help define the target groups of healthy lifestyle, and organise health education campaigns better aimed at the Z Generation.

Kulcsszavak: értékrendalapú élelmiszer-fogyasztói magatartásra vonatkozó modellek, Z generáció, primer kutatás Keywords: value-based food-consumer behaviour model, $Z$ generation, primary research

JEL-kód: M0

\section{BEVEZETÉS}

A téma aktualitását és elméleti bázisát két pillér adja: az értékrendalapú fogyasztói magatartásra vonatkozó elméletek és a generációs marketing.

A fogyasztói magatartásra vonatkozó elméletek közül vizsgálatom fókuszában az értékrendalapú elméletek állnak, melyeknek közös vonása, hogy a fogyasztó termék- és szolgáltatásválasztásának indítékai és az értékrendszer között összefüggést feltételeznek. Ez az alapkoncepció inspirált arra, hogy az értékrend és a fogyasztói magatartás összefüggéseit saját primer kutatás keretében generációspecifikusan elemezzem a $\mathrm{Z}$ generáció élelmiszer-fogyasztói szokásainak, azon belül is az egészséges táplálkozás iránti attitüdjének vizsgálata révén.

A téma másik pillére a generációs marketing, mely a különböző korosztályok közötti eltérések végső eredőjeként szintén az értékrendet nevezi meg. Tekintettel arra, hogy a $Z$ generáció a közeljövő potenciális fizetőképes keresletet teremtő fogyasztói bázisa lesz, meg- ítélésem szerint érdemes és hasznos a generáció sajátos élelmiszer-fogyasztói preferenciájának, döntéseinek megismerése.

Primer vizsgálatom során a $\mathrm{Z}$ generáció tagjaira fókuszáló kvantitatív adatfelvétel keretében elemeztem e generáció értékrendjét, élelmiszer-fogyasztói magatartását és az egészségről, egészséges táplálkozásról alkotott véleményét. A kvantitatív kutatás keretében pedig sztenderdizált kérdőíves megkérdezést folytattam le, melynek eredményeként több mint 500 értékelhető kérdőívet elemeztem ki. A kutatás során szürőfeltétel volt, hogy a vizsgált személyek életkor szerint a Z generáció köréből kerüljenek ki.

Az eredmények alapján megállapítható lesz, hogy a jövő nemzedéke milyen értékorientációval rendelkezik, és mennyire tartja fontosnak egészséget, mit tesz annak megóvása érdekében. Ezen felül a kutatás eredményei segítségével kirajzolódnak a $Z$ generáció körében releváns élelmiszer-fogyasztói magatartásra vonatkozó minták, melyek segítségül szolgálhatnak az egészséges táplálkozás célcsoportjainak definiálásához és a $Z$ generációra irányuló egészségnevelő kam- 
pányokhoz.

\section{ELMÉLETI HÁTTÉR}

\subsection{Az értékrend szerepe az élelmiszer-fogyasztói magatartásban}

A tanulmány elméleti hátterének egyik pillérét az értékrendalapú fogyasztói, élelmiszer-fogyasztói magatartás elméletei adják. Ezen elméletek közös alapja, hogy a vásárlói és fogyasztói döntést az értékrendszer külső vetületeként értelmezik. Ennek megfelelően a fogyasztói magatartást meghatározó tényezők közül kiemelten kezelem az értékrendet mint a fogyasztói magatartás belső összefüggésrendszerét alapvetően determináló tényezőt.

A fogyasztói magatartás interdiszciplináris megközelítése szerint az értékrend két környezeti elemhez, a kulturális és a társadalmi tényezőkhöz köthető. Minden egyes társadalom a saját keretein belül kialakítja kultúrájának érték- és előírásrendszerét, amely bizonyos határokon belül meghatározza tagjai számára a követendő magatartást. A társadalmi tényezőkhöz pedig az életmód, életstílus, státusz dimenziók révén köthető az érték.

A szociológiai és fogyasztásszociológiai megközelítések azonban eltérést mutatnak aszerint, hogy az érték kulturális, társadalmi vagy éppen egyéni determináltságát tartják fontosnak.

Hofmeister-Tóth (2003) szerint az érték kívánt viselkedési formára vagy életmódra vonatkozó, különböző szituációkban érvényesülő, relatív fontosság alapján rendezett tartós koncepció vagy megygyőződés, hit.

$\mathrm{Az}$ érték kulturális determináltságát hangsúlyozza Andorka (2003), Giddens (2003), Hawkins-Best-Coney (1992), akik kulturális alapelvnek, eszmének tekintik az értéket. Ezzel szemben vannak szerzők, akik az érték egyéni meghatározottságát emelik ki. A szubjektivista megközelítés jellemzi például Peter-Olson (1987) definícióját, mely szerint az érték a fogyasztó alapvető szükségleteinek, céljainak kognitív képviselője.

Más szerzők viszont az egyéni meghatározottsággal ellentétben épp az érték társadalmi determináltságát hangsúlyozzák. Gauthier (1986) az érték normatív erejét hangsúlyozza, amikor az értéket a döntés normájaként nevesíti. Hasonlóképp teszi ezt elméletében Hartmann (1972) is, akik szerint az érték normáink forrása.

Megítélésem szerint az elméletek alapján összességében megállapítható, hogy az értékeket tehát az adott csoport kultúrája termeli, de a csoportértékekre a mindennapi életet meghatározó feltételek, körülmények hatnak.

A pszichológiában alkalmazott értékmérő módszerek közül a marketingtudományban az egyik legismertebb a Rokeach-értékrendszer (1973 in Horváth, 1996) és a Mitchell-féle „Értékek és Értékstílusok" (1983 in Horváth, 1996.). A Kahle-féle értékek listája (Kahle, 1985) már a marketingkutatás sajátosságaihoz alkalmazkodó, a fogyasztói magatartás kutatásában jól alkalmazható módszer (Hofmeister, 2003).

$\mathrm{A} z$ értékmérő módszerek fontos szerepet játszanak abban, hogy a marketingkutatás eszköztárát bővítve általuk lehetőségünk nyíljon a fogyasztói preferenciát és a vásárlói döntéshozatal mikéntjét magyarázó, egyénhez kötődő jellemző megalapozott elemzésére. Az értékmérő módszerek egyfajta továbbgondolásával születtek meg azok az értékrendalapú fogyasztói magatartásra vonatkozó modellek, melyek alapját a fent említett módszerekkel lehetővé vált értékmérés jelentette. Ezek a modellek az értékek mérésére alapozva már a termék- és szolgáltatásválasztás indítékait kívánták magyarázni.

Az értékrend és a fogyasztói magatartás összefüggései igazak az élelmiszer-fogyasztás, a táplálkozási szokások elemzésére is. Ezt bizonyítják azon modellek, melyek a táplálkozási döntéseket, az élelmiszer-választást az értékrendre és az életstílusra vezetik vissza. Ezekben a modellekben közös vonás az is, hogy a termékek vagy szolgáltatások elvont értékekeiből indulnak ki és azokkal összefüggésben jutnak el a konkrét termék, élelmiszer vagy szolgáltatás konkrét tulajdonságaihoz. Ilyen Gutman jelentésláncolat-elmélete (in: Lehota, 2001), mely hierarchikus modellként az értékek, a fogyasztás és a konkrét terméktulajdonságok közötti kapcsolatrendszerre világít rá.

Ennek továbbgondolása útján Grunert (1996) megalkotta az élelmiszer-orientált életstílus modelljét, amely szintén az értékrend alapján magyarázza az élelmiszer-felhasználás sajátos helyzeti összetevőit, mint a vásárlás módját, a termékminőség szempontjait, az ételkészítés módozatait, a fogyasztói helyzeteket és a vásárlói motivációkat.

Az értékrendalapú élelmiszer-fogyasztói magatartásra vonatkozó elmélet szerint három szinten realizálódik az értékek élelmiszer-fogyasztási preferenciákra gyakorolt hatása. Az első szinten a fogyasztó általános alapértékei helyezkednek el, mint a béke, a biztonság és az idő. A második szinten a fogyasztói szokásokat determináló értékrendek helyezkednek el, mint például a minőségtudatosság, hedonizmus, időtudatosság. Ezek a fogyasztó társadalmi helyzetéről, preferenciarendszeréről, életkörülményeiről tanúskodnak. Végül a harmadik szinten találhatóak a konkrét termék és szolgáltatás értékei, mint például a termék-, szolgáltatásválasztási indítékok (Horváth, 1996).

Ezen elméletek alapkoncepciója inspirált arra, hogy az értékrend és a fogyasztói magatartás összefüggéseit vizsgáljam. Ezt első ízben egy 2008-as, hazai mintán lefolytatott kutatásom keretében tettem meg, melynek eredményei igazolták, hogy az értékrendalapú fogyasztói magatartásra vonatkozó elméletek érvényesek az élelmiszer-fogyasztásra és annak egy speciális ágára, a munkahelyi étkeztetés szolgáltatására (Fodor, 2008).

Ennek eredményeként sikerült a munkahelyi étkezés értékrendalapú fogyasztói magatartásra vonatkozó modelljét megalkotnom és a kutatásom eredményeinek tükrében a modellt validálnom.

Ugyanezen összefüggésrendszert sikerült igazolnunk egy 2016-os kutatás során, amikor is a pénz értékének megítélése és a pénzzel való gazdálkodás, pénzügyi döntés mikéntje között összefüggést mutattuk ki, igazolva ezzel azt, hogy az értékrendalapú fogyasztói magatartásra vonatkozó elméletek alapösszefüggése érvényes a pénzzel kapcsolatos döntések terén is (Fodor-Csiszárik, 2018)

\subsection{A Z generáció sajátosságai a generációs marketing aspektu- sából}

A tanulmány másik fontos elméleti bázisát a generációs marketing koncepciója adja, melynek keretében a $\mathrm{Z}$ generációra vonatkozó fogyasztói jellemzők ismertetésére törekszem.

A generációs marketing alapkoncepciója szerint jellemezhetőek az egyes generációk a rájuk kifejezetten jellemző közös értékek mentén. Az értékek, a közös élmények, azok az azonosságok, amelyek lehetöséget teremtenek arra, hogy általuk jellemezhessünk egy-egy generációt, hiszen ezek az ismérvek kapcsolják össze az embereket, jelentenek egyfajta rendező elvet a sokféle egyéni sors, történet, jellemző között. A generációkon belül fellelhető azonosságok keretezik az odatartozó emberek döntéseit, és egyben megkülönböztetik a többi generációtól (Törőcsik, 2003). 
A generációk magatartás-vizsgálatának fontos aspektusa az értékorientáció vizsgálata, az abban rejlő különbözőségek meghatározása (Schewe és Noble, 2000). A koncepció lényege, hogy az életkor szigorú lehatárolása mellett azt is figyelembe kell venni, hogy az egyes generációkhoz tartozóknak karakteresen más csoportélményei vannak. A generációs elméleten alapuló marketingszemlélet kiindulópontja, hogy a szocializáció során megtapasztalt nagyobb és meghatározó történések, a „korszellem” elkíséri az embereket életük végéig, hatással van választásaikra. A tanulmányban a $Z$ fogyasztókra fókuszálok, ezért erről a generációról adok röviden jellemzést.

A Z generáció tagjai primer kutatásom célcsoportja. Hazánkban Tari (2010; 2011) foglalkozott mélyebben az Y és a $Z$ generációval. Jellemzése szerint a $Z$ generáció ismert úgy is, mint „új-konzervatívok”, „Facebook-generáció”, digitális bennszülöttek, „Instant online” korosztály, netgeneráció, iGeneráció. Előbbiek miatt gyakran nevezik őket $\mathrm{C}$ generációnak, amely az angol connection szóból származik, illetve D-nek, amely a digitális szóra utal, de R-nek is, amely az angol responsibility, vagyis felelősség kifejezésből származik. A Z generáció kapcsán fontos kiemelni, hogy nem szabad csupán úgy tekinteni rájuk, mint egy generáció a többi között, hiszen ők a világ első globális nemzedéke, akik ugyanazon a kultúrán nőnek fel, és ugyanazokat az ételeket, divatot, helyeket szeretik. A globalitás nyelvi eszköztárukra is jellemző. Olyan szavakat, kifejezéseket használnak, amelyeket más generáció nem vagy alig ért. A $Z$ generációnak ugyanolyan problémáik vannak, mint a megelőző időszak fiataljainak, az identitáskeresés, az élet nagy kérdéseinek feszegetése, a megfelelés stb., de a technikai lehetőségek új kereteket adnak életüknek, ami hirtelen még inkább érthetetlenné teszi magatartásukat az idősebbek számára. E generáció környezettudatosabb, és érzékenyebb a társadalmi kérdésekre, mint a korábbi generációk bármelyike. Ezzel összhangban a hagyományos vásárlás a fiatalok esetében már nem dominál, a vásárlás színtere is áthelyeződött az online világba, a vásárlás, az üzletekben való bolyongás esetükben nem jellemző, és élményfaktorral sem bír számukra. Szakértői vélemények szerint akkor tudunk a legjobban illeszkedni az új generáció igényeihez, ha azokat a tevékenységeket, amelyekbe szeretnénk őket bevonni, minél inkább közösségivé tudjuk tenni, úgy, ahogy az számukra közösségi élmény, közösségi tér tud lenni. A fiatal generáció számára élmények kellenek: kóstolás, érintés, ámulat, csodálat, borzongás, egyszóval a szórakoztatás a kulcsszó a nekik pozicionált szolgáltatások, termékélmények esetén (Törőcsik, 2003; 2017).

\section{ANYAG ÉS MÓDSZER}

Jelen kutatásban a $Z$ generációra fókuszálva kívánom igazolni az élelmiszer-fogyasztás és értékrendszer alapösszefüggéseit generációspecifikus megvilágításban.

Kutatásom egyik hipotézise (H1), hogy az az élelmiszer-fogyasztói preferencia alapján e generáció tagjai specifikálhatóak, egymástól jól elkülöníthető szegmensek rajzolhatóak ki a fent említett leíró változó alapján.

Másik hipotézisem (H2), hogy a Z generáció élelmiszer-fogyasztása esetén is érvényes az értékrendalapú fogyasztói magatartásra vonatkozó elméletek alapösszefüggése, azaz az élelmiszer-fogyasztói preferencia szerint kialakult csoportok értékorientációja szignifikánsan különbözik egymástól.

Primer adatfelvétel keretében kvantitatív módszert alkalmazva elemeztem a $Z$ generáció értékrendjét, élelmiszer-fogyasztói magatar- tását és az egészségről, egészséges táplálkozásról alkotott véleményét.

A kvantitatív kutatás keretében sztenderdizált kérdőíves megkérdezést folytattam le, melynek eredményeként több mint 500 értékelhető kérdőívet elemeztem ki. A kvantitatív kutatáshoz az alanyok rekrutálása hólabda mintavételi módszerrel valósult meg. A kutatás során szürőfeltétel volt, hogy az alanyok életkor szerint a $Z$ generáció köréből kerüljenek ki.

\section{EREDMÉNYEK ÉS KIÉRTÉKELÉSÜK}

Első hipotézisem (H1) vizsgálata érdekében első ízben az élelmiszer-fogyasztói preferenciákat elemeztem a mintatagok körében.

$\mathrm{Az}$ eredmények alapján megállapíthattam, hogy a legfontosabb szempont egy élelmiszer megválasztásában annak frissessége lett, ahogy ez az 1. táblázatban látható. A második legmérvadóbb mérlegelendő tényező, hogy megérje az árát, melyet az élelmiszer jó íze, illata követett.

A tény, hogy az élelmiszer olcsó mivolta háttérbe szorult a beltartalmi értékek (vitamin-, ásványianyag-tartalom, mesterséges anyagoktól való mentesség) és a külső jegyekkel szemben is azt mutatja, hogy ennél a generációnál az árérzékenység kevésbé jellemző. Természetesen ez nemcsak egyéni élelmiszer-fogyasztói preferencia függvénye, hanem vélelmezhetően azzal is összefüggésben áll, hogy az alanyok többsége nem önálló jövedelemből gazdálkodik, hanem még szüleivel egy háztartásban él.

\section{1. táblázat: Élelmiszer-fogyasztói preferenciák a mintában}

\begin{tabular}{|l|c|c|}
\hline \multicolumn{1}{|c|}{ Élelmiszer megválasztásának szempontjai } & $\begin{array}{c}\text { átlag } \\
\text { (ahol 1=egyálta- } \\
\text { lán nem fontos, } \\
4=\text { teljes mérték- } \\
\text { ben fontos) }\end{array}$ & szórás \\
\hline frissesség & 3,68 & 0,60 \\
\hline alacsony kalóriatartalom & 2,33 & 0,91 \\
\hline biominöség & 2,11 & 0,88 \\
\hline olcsó legyen & 2,75 & 0,82 \\
\hline jó iz, illat & 3,62 & 0,62 \\
\hline szép külsó megjelenés & 3,11 & 0,80 \\
\hline földrajzi eredet, származási hely & 2,31 & 0,96 \\
\hline magas táplálórték & 2,74 & 0,88 \\
\hline vitamin-, ásványianyag-tartalom & 2,88 & 0,90 \\
\hline praktikus csomagolás & 2,64 & 0,84 \\
\hline gyors elkészíthetöség & 2,92 & 0,90 \\
\hline márkanév & 2,44 & 0,90 \\
\hline az élelmiszer mesterséges anyagoktól mentes legyen & 2,78 & 0,91 \\
\hline hosszú eltartbatóság & 2,71 & 0,86 \\
\hline megérje az árát & 3,63 & $\mathbf{0 , 6 5}$ \\
\hline megfelelö méretü kiszerelés & 3,18 & 0,77 \\
\hline újrahasznosítható, környezetbarát csomagolás & 2,71 & 0,93 \\
\hline
\end{tabular}


Annak érdekében, hogy igazolni tudjam az élelmiszer-fogyasztói preferenciák alapján szegmentálható, a minta, az élelmiszer megválasztásában szerepet játszó tényezőkre, faktoranalízist folytattam le.

Három-, négy- és ötfaktoros próba eredményét elemeztem, szakmailag a legjobb magyarázatot a négyfaktoros megoldás adta:

Ennek eredményeként az alábbi faktorokat tudtam definiálni (2. táblázat):

+ Egészség- és környezettudatosság, ahol az élelmiszer beltartalmi elemei, magas vitamin- és ásványianyag-tartalma mellett olyan szempontok is szerepeltek, mint az újrahasznosíthatóság, földrajzi eredet, biominőség. Ezek a tényezők már egy tudatos, az egészség- és környezetvédelem együttes szempontrendszerét figyelembe vevő tényezőkört jelentenek.

+ Idő és ár, ahol az eltarthatóság, a gyors elkészíthetőség, azaz az időhöz, az idő megtakarításához kötődő elemek kerültek az árral kapcsolatos tényezők mellé.

+ Érzékszervi elemek, melyek a látható, érzékelhető tulajdonságokat - úgy, mint frissesség, íz és illat - foglalták magukba.

+ Design és kommunikáció, egy olyan faktorcsoport, melyben a praktikusság, a külsőség és a márkanév kaptak helyet.
Annak érdekében, hogy az élelmiszer-fogyasztás szempontrendszer szerint szegmentálni tudjam a mintát, a teljes tényezőlistára $\mathrm{K}$-means eljárással lefolytatott klaszteranalízist végeztem.

Ennek eredményeként a következő szegmenseket tudtam elkülöníteni egymástól (3. táblázat):

+ Egészség- és környezettudatos szegmens, akik az egészségés környezettudatosság faktorcsoportjához tartozó szempontokat értékelték a többi szegmenshez és a mintához képest is felül.

+ Mindent felülértékelő, nem árérzékeny fogyasztók, akik az olcsóság kritériumától eltekintve az összes szempontot fontosabbnak ítélték, mint a mintaátlag.

+ Preferencia nélküliek, akik számára egyetlen szempont sem volt fontosabb, mint a teljes mintaátlag. Ők azok a fogyasztók, akik vélelmezhetően még nem rendelkeznek kiforrott magatartásmintával, preferenciarendszerük még kiforratlan, befolyásolható.

+ Idő- és ártudatosak, akik számára a gyorsaság, az időhöz kötődő elemek és az árhoz kapcsolódó tényezők játszottak átlagon felül fontos szerepet az élelmiszer kiválasztásában.

2. táblázat: Élelmiszer kiválasztásában szerepet játszó tényezők rotált faktormátrixa

\begin{tabular}{|c|c|c|c|c|}
\hline Élelmiszer megválasztásának szempontjai & $\begin{array}{c}\text { Egészség- és } \\
\text { környezettudatosság }\end{array}$ & Idő és ár dimenziói & $\begin{array}{c}\text { Érzékszervi } \\
\text { elemek }\end{array}$ & $\begin{array}{c}\text { Design és } \\
\text { kommunikáció }\end{array}$ \\
\hline vitamin-, ásványianyag-tartalom & 0,78676 & 0,037005 & 0,128931 & $-0,00616$ \\
\hline az élelmiszer mesterséges anyagoktól mentes legyen & 0,76487 & 0,040316 & 0,07004 & 0,150526 \\
\hline biominöség & 0,74578 & 0,071571 & $-0,1266$ & 0,009187 \\
\hline újrahasznositható, környezetbarát csomagolás & 0,70652 & 0,085475 & 0,136874 & 0,026998 \\
\hline magas táplálóérték & 0,698 & 0,061657 & 0,084324 & $-0,06675$ \\
\hline földrajzi eredet, származási bely & 0,60981 & $-0,25351$ & 0,024441 & 0,358147 \\
\hline alacsony kalóriatartalom & 0,39509 & 0,361324 & $-0,1959$ & 0,019246 \\
\hline gyors elkészithetöség & $-0,1071$ & 0,68764 & $-0,09003$ & 0,216979 \\
\hline bosszú eltarthatóság & 0,159716 & 0,67593 & 0,027882 & 0,106936 \\
\hline megérje az árát & 0,105523 & 0,59541 & 0,485745 & $-0,00733$ \\
\hline olcsó legyen & $-0,09438$ & 0,53456 & 0,252734 & $-0,11076$ \\
\hline megfelelö méretü kiszerelés & 0,175099 & 0,48357 & 0,267709 & 0,268561 \\
\hline jó iz, illat & $-0,02398$ & 0,173588 & 0,80037 & 0,145475 \\
\hline frissesség & 0,163343 & 0,044012 & 0,77329 & $-0,06164$ \\
\hline márkanév & $-0,01639$ & 0,183361 & $-0,12872$ & 0,80903 \\
\hline szép külső megjelenés & 0,022518 & 0,010986 & 0,469521 & 0,63328 \\
\hline praktikus csomagolás & 0,338598 & 0,364455 & 0,086516 & 0,46666 \\
\hline
\end{tabular}


3. táblázat: Élelmiszer-fogyasztói szegmensek a mintában

\begin{tabular}{|l|c|c|c|c|c|}
\hline \multicolumn{5}{|c|}{ Élelmiszer-preferencia szerinti klaszterek } \\
\hline \multicolumn{1}{|c|}{ Élelmiszer-választás szempontjai } & $\begin{array}{c}\text { Egészség-és } \\
\text { környezettudatos } \\
\text { szegmens } \\
\mathrm{N}=220\end{array}$ & $\begin{array}{c}\text { Mindent } \\
\text { felülértékelök } \\
\text { csoportja } \\
\mathrm{N}=120\end{array}$ & $\begin{array}{c}\text { Preferencia } \\
\text { nélküliek } \\
\text { köre } \\
\mathrm{N}=56\end{array}$ & $\begin{array}{c}\text { Idö- és } \\
\text { ártudatos } \\
\text { csoport } \\
\mathrm{N}=150\end{array}$ & $\begin{array}{c}\text { Minta } \\
\mathrm{N}=546\end{array}$ \\
\hline frissesség & 3,81 & 3,72 & 3,11 & 3,67 & 3,68 \\
\hline alacsony kalóriatartalom & 2,32 & 2,87 & 2,04 & 2,03 & 2,33 \\
\hline biominöség & 2,19 & 2,90 & 1,79 & 1,47 & 2,11 \\
\hline olcsó legyen & 2,83 & 2,70 & 1,93 & 2,97 & 2,75 \\
\hline jó iz, illat & 3,66 & 3,73 & 3,00 & 3,71 & 3,62 \\
\hline szép külsö megjelenés & 3,05 & 3,45 & 2,57 & 3,12 & 3,11 \\
\hline földrajzi eredet, származási bely & 2,44 & 3,05 & 2,04 & 1,64 & 2,31 \\
\hline magas táplálóérték & 2,92 & 3,55 & 2,39 & 1,97 & 2,74 \\
\hline vitamin-, ásványianyag-tartalom & 3,19 & 3,63 & 2,29 & 2,05 & 2,88 \\
\hline praktikus csomagolás & 2,52 & 3,45 & 1,71 & 2,53 & 2,64 \\
\hline gyors elkészíthetöség & 2,78 & 3,18 & 2,18 & 3,19 & 2,92 \\
\hline márkanév & 2,14 & 2,95 & 1,93 & 2,65 & 2,44 \\
\hline az élelmiszer mesterséges anyagoktól mentes legyen & 3,00 & 3,58 & 2,00 & 2,09 & 2,78 \\
\hline hosszú eltarthatóság & 2,48 & 3,40 & 1,75 & 2,84 & 2,71 \\
\hline megérje az árát & 3,65 & 3,85 & 2,50 & 3,84 & 3,63 \\
\hline megfelelö méretü kiszerelés & 3,22 & 3,53 & 2,18 & 3,23 & 3,18 \\
\hline újrahasznosítható, környezetbarát csomagolás & 2,95 & 3,45 & 1,89 & 2,08 & 2,71 \\
\hline
\end{tabular}

A H2 hipotézisem - miszerint a Z generáció értékorientációja és élelmiszer-fogyasztói magatartásra vonatkozó mintája között összefüggés mutatható ki - vizsgálata érdekében az élelmiszer-fogyasztói preferencia szerint kirajzolódott szegmensek esetén varianciaanalízis segítségégével megnéztem, hogy statisztikailag igazolható-e, hogy az egyes élelmiszer-fogyasztói csoportok értékrend szerint differenciálhatóak (4, táblázat).

A varianciaanalízis eredménye szerint $(\mathrm{szig}=0,000)$ minden egyes vizsgálatba vont értékdimenziók alapján szignifikánsan különböznek egymástól az élelmiszer-fogyasztói szegmensek.

$\mathrm{A} z$ eredmények alapján azt tapasztalhattam, hogy az egészség- és környezettudatos élelmiszer-fogyasztók számára a szabadság, barátság, nyugodt, kiegyensúlyozott élet, egészség, jó emberi kapcsolatok, belső harmónia, nyugodt élet mintaátlagon felül fontos szempontok. Ök azok a fiatalok, akik a karrier megvalósítása mellett a tradicionális értékek követői, és akiknek az élelmiszer-fogyasztói magatartása és az értékrendje, gondolkodásmódja nagyon szorosan kapcsolódik egymáshoz.

$\mathrm{A} z$ idő- és ártudatos élelmiszer-fogyasztók értékrendjüket tekintve a szabadságot, szabadidőt, az élvezetes életet, anyagi jólétet priorizálók köre, azaz a hedonisztikus értékek követői, mely értékorientáció összhangban áll élelmiszer-fogyasztói attitűdjükkel.

$\mathrm{A} z$ eredmények alapján azt is megállapíthattam, hogy akik az élelmiszer-fogyasztói preferenciák terén minden dimenziót felülértékeltek, azok az értékrendjükben is hasonló képet mutatnak, és ez igaz azokra is, akik számára nem volt igazán semmi fontos: őket ez a fajta preferencianélküliség jellemzi élelmiszer-fogyasztási szokásaik terén épp úgy, mint az emberi értékek megítélésének vonatkozásában. 
4. táblázat: Élelmiszer-fogyasztói magatartásra vonatkozó minták jellemzése értékrend alapján

\begin{tabular}{|c|c|c|c|}
\hline értékek & klaszterek & elemszám & átlag \\
\hline \multirow{5}{*}{ szabadság } & egészség-és környezettudatos & 220 & 3,7818182 \\
\hline & mindent felülértékelő & 120 & 3,7333333 \\
\hline & mindent alulértékelő & 56 & 3,3571429 \\
\hline & idő- és ártudatos & 150 & 3,7866667 \\
\hline & minta & 546 & 3,7289377 \\
\hline \multirow{5}{*}{ élvezetes élet } & egészség-és környezettudatos & 220 & 3,7727273 \\
\hline & mindent felülértékelő & 120 & 3,7833333 \\
\hline & mindent alulértékelő & 56 & 3,3214286 \\
\hline & idő- és ártudatos & 150 & 3,8266667 \\
\hline & minta & 546 & 3,7435897 \\
\hline \multirow{5}{*}{ anyagi jólét } & egészség- és környezettudatos & 220 & 3,5272727 \\
\hline & mindent felülértékelő & 120 & 3,65 \\
\hline & mindent alulértékelő & 56 & 3,2142857 \\
\hline & idő- és ártudatos & 150 & 3,8 \\
\hline & minta & 546 & 3,5970696 \\
\hline \multirow{5}{*}{ igazi barátság } & egészség- és környezettudatos & 220 & 3,8363636 \\
\hline & mindent felülértékelő & 120 & 3,7666667 \\
\hline & mindent alulértékelő & 56 & 3,4285714 \\
\hline & idő- és ártudatos & 150 & 3,88 \\
\hline & minta & 546 & 3,7912088 \\
\hline \multirow{5}{*}{ nyugodt, kiegyensúlyozott élet } & egészség- és környezettudatos & 220 & 3,8363636 \\
\hline & mindent felülértékelő & 120 & 3,8666667 \\
\hline & mindent alulértékelő & 56 & 3,3214286 \\
\hline & idő- és ártudatos & 150 & 3,76 \\
\hline & minta & 546 & 3,7692308 \\
\hline \multirow{5}{*}{ egészség } & egészség-és környezettudatos & 220 & 3,8909091 \\
\hline & mindent felülértékelő & 120 & 3,8666667 \\
\hline & mindent alulértékelő & 56 & 3,25 \\
\hline & idő- és ártudatos & 150 & 3,7866667 \\
\hline & minta & 546 & 3,7912088 \\
\hline \multirow{5}{*}{ jó emberi kapcsolatok } & egészség- és környezettudatos & 220 & 3,7909091 \\
\hline & mindent felülértékelő & 120 & 3,8 \\
\hline & mindent alulértékelő & 56 & 3,25 \\
\hline & idő- és ártudatos & 150 & 3,68 \\
\hline & minta & 546 & 3,7069597 \\
\hline \multirow{5}{*}{ sok szabadidő } & egészség- és környezettudatos & 220 & 3,4545455 \\
\hline & mindent felülértékelő & 120 & 3,5 \\
\hline & mindent alulértékelö & 56 & 3,1071429 \\
\hline & idő- és ártudatos & 150 & 3,4933333 \\
\hline & minta & 546 & 3,4395604 \\
\hline \multirow{5}{*}{ megengedhessek magamnak valami jót } & egészség- és környezettudatos & 220 & 3,5181818 \\
\hline & mindent felülértékelő & 120 & 3,6333333 \\
\hline & mindent alulértékelő & 56 & 3,1428571 \\
\hline & idő- és ártudatos & 150 & 3,6933333 \\
\hline & minta & 546 & 3,5531136 \\
\hline \multirow{5}{*}{ takarékosság } & egészség- és környezettudatos & 220 & 3,3181818 \\
\hline & mindent felülértékelő & 120 & 3,5166667 \\
\hline & mindent alulértékelő & 56 & 2,8928571 \\
\hline & idő- és ártudatos & 150 & 3,12 \\
\hline & minta & 546 & 3,2637363 \\
\hline \multirow{5}{*}{ másoknak való örömszerzés } & egészség- és környezettudatos & 220 & 3,5090909 \\
\hline & mindent felülértékelő & 120 & 3,6666667 \\
\hline & mindent alulértékelő & 56 & 3,2142857 \\
\hline & idő- és ártudatos & 150 & 3,48 \\
\hline & minta & 546 & 3,5054945 \\
\hline
\end{tabular}




\begin{tabular}{|c|c|c|c|}
\hline értékek & klaszterek & elemszám & átlag \\
\hline \multirow{5}{*}{ belső harmónia } & egészség- és környezettudatos & 220 & 3,7 \\
\hline & mindent felülértékelő & 120 & 3,7833333 \\
\hline & mindent alulértékelő & 56 & 3,1428571 \\
\hline & idő- és ártudatos & 150 & 3,5866667 \\
\hline & minta & 546 & 3,6300366 \\
\hline \multirow{5}{*}{ boldog családi élet } & egészség- és környezettudatos & 220 & 3,7363636 \\
\hline & mindent felülértékelő & 120 & 3,8333333 \\
\hline & mindent alulértékelő & 56 & 3,4285714 \\
\hline & idő- és ártudatos & 150 & 3,7733333 \\
\hline & minta & 546 & 3,7362637 \\
\hline \multirow{5}{*}{ karrier, szakmai siker, önmegvalósítás } & egészség- és környezettudatos & 220 & 3,7272727 \\
\hline & mindent felülértékelő & 120 & 3,6666667 \\
\hline & mindent alulértékelő & 56 & 3,3214286 \\
\hline & idő- és ártudatos & 150 & 3,6266667 \\
\hline & minta & 546 & 3,6446886 \\
\hline \multirow{5}{*}{ hobbi } & egészség- és környezettudatos & 220 & 3,3909091 \\
\hline & mindent felülértékelő & 120 & 3,35 \\
\hline & mindent alulértékelő & 56 & 3,0714286 \\
\hline & idő- és ártudatos & 150 & 3,2133333 \\
\hline & minta & 546 & 3,3003663 \\
\hline \multirow{5}{*}{ békés élet } & egészség- és környezettudatos & 220 & 3,7454545 \\
\hline & mindent felülértékelő & 120 & 3,7833333 \\
\hline & mindent alulértékelő & 56 & 3,1071429 \\
\hline & idő- és ártudatos & 150 & 3,6266667 \\
\hline & minta & 546 & 3,6556777 \\
\hline \multirow{5}{*}{ másokon való gondoskodás } & egészség- és környezettudatos & 220 & 3,4090909 \\
\hline & mindent felülértékelő & 120 & 3,65 \\
\hline & mindent alulértékelő & 56 & 3 \\
\hline & idő- és ártudatos & 150 & 3,2 \\
\hline & minta & 546 & 3,3626374 \\
\hline
\end{tabular}

\section{KONKLÚZIÓK}

A Z generáció élelmiszer-fogyasztói szokásait vizsgáltam első ízben és az élelmiszer-fogyasztói preferencia alapján jól elkülöníthető fogyasztói csoportokat tudtam karakterizálni. Ezzel igazolva H1 hipotézisemet, miszerint az élelmiszer-fogyasztói preferencia alapján e generáció tagjai jól specifikálhatóak. A klaszterezési eljárás eredményeként négy fogyasztói szegmenst tudtam megkülönböztetni: az „egészség- és környezettudatos klasztert”, melynek tagjai az egészség- és környezettudatosság faktorcsoportjához tartozó szempontokat értékelték felül, a „mindent felülértékelő nem árérzékeny fogyasztókat", akik az olcsóság kritériumától eltekintve az összes szempontot fontosabbnak ítélték, mint a mintaátlag, a „preferencia nélkülieket", akik számára egyetlen szempont sem volt igazán mérvadó; valamint az „idő- és ártudatosok körét”, akik számára a gyorsaság, az időhöz kötődő elemek és az árhoz kapcsolódó tényezők játszottak átlagon felül fontos szerepet egy élelmiszer kiválasztásában.

A második hipotézisem vizsgálata céljából ezen szegmenseket értékrend alapján is jellemeztem. A varianciaanalízis eredménye szerint (szig $=0,000)$ minden egyes vizsgálatba vont értékdimenzió alapján szignifikánsan különböztek egymástól az élelmiszer-fogyasztói szegmensek, ezzel igazolva második hipotézisemet, azaz hogy az élelmiszer-fogyasztói preferencia szerint kialakult csoportok értékorientációja szignifikánsan különbözik egymástól.

\section{6. ÖSSZEFOGLALÁS}

A tanulmány fó célja, hogy a $Z$ generáció értékrendjét, élelmiszer-fogyasztói magatartását és az egészségről, egészséges táplálkozásról alkotott véleményét vizsgálja szekunder és primer kutatási eredmények alapján.

Célom volt annak bizonyítása, hogy az értékrendalapú fogyasztói magatartásra vonatkozó modellek alapkoncepciója érvényes az általam vizsgálatba vont $Z$ generáció tagjaira.

A vizsgált téma elméleti bázisát az értékrendalapú fogyasztói magatartásra vonatkozó elméletek és a generációs marketing adták. Az értékrendalapú élelmiszer-fogyasztói magatartásra vonatkozó elméletek alapkoncepciója szerint a fogyasztó termék- és szolgáltatásválasztásának indítékai és az emberi értékek megítélése között összefüggés van: azaz az élelmiszer-választást a fogyasztói értékrendre vezetik vissza.

Ezt az alapkoncepciót követve az értékrend és az élelmiszer-fogyasztói magatartás összefüggéseit saját primer vizsgálat keretében generációspecifikusan elemeztem.

Összességében megállapíthattam, hogy az élelmiszer-fogyasztói döntések és az alapvető emberi értékek megítélése alapján összhangot mutatnak az egyes csoportok.

$\mathrm{A} z$ eredmények alapján a $Z$ generáció tagjainak élelmiszer-fogyasztói szokásai mellett értékrendjéről is árnyalt képet 
kaphatunk, mely meglátásom szerint fontos támpont egy, az adott generációnak szóló marketingaktivitások körének megválasztásában. Az egyes szegmensek karakterizálása a differenciált marketingstratégia kialakításához tud támpontot adni, mely meglátásom szerint hasznos információk forrása lehet az élelmiszer-forgalmazók és -gyártók számára.

$\mathrm{A} z$ élelmiszer-fogyasztói preferencia alapján négy célcsoportot definiáltam a primer kutatás eredményeként. A szegmensek jellemzése és értékrendjükben megmutatkozó sajátosságaik leírása segíthet kijelölni a targetált marketingaktivitások körét.

A kutatás korlátai közé tartozik, hogy az eredmények az adott mintára érvényesek, ezt a korlátot a kutatás folytatásaként egy országos reprezentatív mintavétellel kívánom feloldani. A kutatás további lépéseként tervezem kvalitatív eljárás lefolytatását is a mélyebb és árnyaltabb eredmények elérése érdekében.

\section{IRODALOM}

Andorka R. (2003). Bevezetés a szociológiába. Budapest: Osiris Kiadó.

Fodor M (2009). Az élelmiszerfogyasztói preferenciák a munkahelyi étkeztetésben. [PhD-disszertáció]. Gödöllő: Szent István Egyetem.

Garia-Fodor M. \& Csiszárik-Kocsír, Á. (2018). The validity of value-based consumer behavioral models in the financial consciousness of the $\mathrm{Z}$ generation, On-line Journal Modelling The New Europe, (27) 107-131. doi: 10.24193/ojmne.2018.27.05

Gauthier D. (1986). Morals by Agreement Clarendon Press Oxford In: S. Nagy, K. (szerk.), Értékek és Normák interdiszciplináris megközelítésben. (p. 223.). Budapest: Gondolat Kiadó.
Giddens, A. (1990). The Consequences of Modernity, Cambridge: Polity Press.

Hartmann N. (1972). Az erkölcsi követelmények lényegéről. Budapest: Gondolat Kiadó (Lételméleti vizsgálatok).

Hawkins, D. I., Best, R. J. \& Coney K. A. (1992). Consumer Behavior 5 th ed. Boston: Irwin.

Hofmeister-Tóth Á. (2003): Fogyasztói magatartás. Budapest: Aula Kiadó.

Horváth, A. (1996). A fogyasztói magatartás és az élelmiszerfogyasztás jellemzői. [PhD-disszertáció], Gödöllő: GATE.

Kahle, L. R., Beatty, S. E. \& Homer, P. E. (1986). Alternative Measurement Approaches to Consumer Values: The List of Values (LOV) and Values and Lifestyles (VALS) Journal of Consumer Research, 13(3), 405. doi: 10.1086/209079

Lehota J. (szerk): (2001). Élelmiszergazdasági marketing, Budapest: Müszaki Kiadó.

Peter J. P. \& Olson J. C. (1987). Consumer Behavior, Homewood, III.* Irwin.

Schewe, C. D. \& Nobel, S. M. (2000). Market Segmentation by Cohorts: The Value and Validity of Cohorts in America and Abroad. Journal of Marketing Management, 16(1-3), 129-142. doi: 10.1362/026725700785100479

Tari A. (2010). Y generáció - Klinikai pszichológiai jelenségek és társadalomlélektani összefüggések az információs korban, Jaffa Kiadó, Budapest.

Tari A. (2011). Z generáció. Budapest: Tercium Könyvkiadó.

Törőcsik M. (2003). Fogyasztói magatartás - Trendek. Budapest: $\mathrm{KJK}$.

Törőcsik M. (2017). Self-marketing, Budapest: Akadémiai Kiadó. 